Pecvnia, 2 (2006), pp. 101-127

\title{
Accounting Models and Devolution in the Italian Public Sector
}

\author{
Aldo Pavan \\ Elisabetta Reginato \\ Gianluca Mudu
}

En la Italia los años 90, se inició un proceso de reforma administrativa del sector público en consonancia, en términos generales, con el movimiento New Public Management. En concreto, se han introducido modificaciones en los sistemas contables y presupuestarios del Estado, de las corporaciones locales y de las instituciones sanitarias. Durante el mismo periodo se emprendió una reforma de carácter constitucional cuyo objetivo último parecía ser la constitución de un estado federal. A partir de los desafíos que supone todo proceso de descentralización, el artículo abre dos interrogantes: 1) la posibilidad de encontrar rasgos comunes en los sistemas contables reformados de los distintos niveles organizativos del sector público, con el fin de confirmar uno o varios modelos contables italianos y, 2) apreciar si estos modelos tienen la capacidad adecuada de una información que satisfaga las necesidades informativas en lo que se refiere a credibilidad, coordinación gubernamental
In the 1990s Italy started a public sector administrative reform process consistent, in general terms, with the New Public Management movement. In particular, changes have been introduced in the budgeting and accounting systems of the State, municipalities, health care bodies, etc. In the same years an institutional reform also started and a strong power devolution process began to be realised; a shift to a federal form of the State seems to be the goal. Starting from the challenges coming from the devolution process, the article questions 1) if it is possible to find some shared features in the reformed accounting systems of the different public sector organisation categories, and to shape in this way one or more accounting Italian models, and 2) if these models have an information capacity adequate to sustain the information needs - in terms of accountability, government 
y toma de decisiones que resulten de ese proceso de descentralización. Se identifican las necesidades de información que se suscitan en la descentralización y se analizan y comparan once sistemas presupuestarios y contables. Igualmente, se discute el aspecto del grado de coherencia entre las reformas constitucionales y contables.

Palabras clave: modelos contables, devolución, sector público italiano, necesidades informativas, reformas contables y de presupuesto, federalismo fiscal. co-ordination and decision making - emerging from the devolution process. The information needs in a devolved environment are recognised; eleven budgeting and accounting systems are analysed and compared. The issue of the consistency level existing between accounting and institutional reforms is also discussed.

Key words: accounting models, devolution, Italian public sector, information needs, budgeting and accounting reforms, fiscal federalism.

\section{INTRODUCTION}

On the waves of the international New Public Management movement (Hood 1991 and 1995; Lapsley and Pallot 2000), and because of several internal factors such as public finance crises and corruption scandals (della Porta and Vannucci 1999), at the beginning of the 1990s Italy started a reform process at both the institutional and administrative level (Anselmi 2003; Ladu 2001; Mussari et al. 2003).

The Italian Republic institutional model is based, at large, on State, regions and municipalities. The framework shaped by the 1948 Constitutional Act was based, at the three mentioned political levels, on assemblies elected by citizens according to a proportional representation voting system, and on governments appointed by the same assemblies. For decades Italy was characterised by low profile unstable executive bodies, with most of the power centralised at the state level. The institutional reform process seems to go towards two directions. On the one hand, at the local and regional level, governments are strengthened by the direct election either of the mayor or of the executive president; on the other hand, a considerable part of the political powers are devolved to regions and municipalities. At the State level the institutional reform is still on the way, two elected assemblies appoint a government, whose powers and stability are not always ensured.

Along with this reform process, heading $\mathrm{V}$ of the Constitutional Act has been reviewed and the subsidiarity principle introduced. This principle, explicitly regarded in the Maastricht Treaty as a fundamental one for the European Union, devolves public functions to lower-tier authorities. Such new constitutional order provides for the 
introduction of spending and tax levying responsibilities to regions and municipalities, which some refer to as "fiscal federalism" (Borgonovi 1996: 233). Its topic addresses the vertical structure of the public sector, laying out a general normative framework for the assignment of functions to different government levels and the appropriate fiscal instruments for carrying out these functions (Oates 1999). In this way the term "federalism" is used in an economic sense, different from its standard use in political science, where it refers to a political system with a constitution that guarantees some range of autonomy and power to both central and decentralised levels of government (Elazar 1987).

As the institutional reform at the state level is still undefined, we could expect a strong but problematic growth of local and regional governments at the expense of the central state. The actual situation is quite different: as a matter of fact, the public finances are still centralised since taxation power has not been relevantly devolved. The subsidiarity principle seems not to be applied consistently, neither is the relationship between taxes levied and public services provided. There is a growing discussion between central and regional governments on this core topic. As for the local governments, they seem to fear the new regional powers more than the traditional state ones. The stakes of this game are the financial powers that regions and municipalities require and the central government does not want to devolve. In this situation it seems that the expression "fiscal federalism" is unsuitable for the present Italian institutional framework, and it is probably better to speak about some degree of "financial devolution" (Della Cananea 2002).

In a country where people are often presented, from a cultural point of view, as fatalist and lacking civil virtues (Hood 1998), the possibility that Italy could have no benefits in terms of democracy and accountability from the devolution of powers and the future transition to the federal state cannot be ruled out. On the contrary, some typical devolution faults may arise: the clash amongst ethnic, social, and linguistic diversities, the increasing unbalance between rich and poor areas (Dahrendhorf 2001), the lack of efficiency and corruption weaknesses that often characterise local bureaucracies, the financial control loss and public expenditure growth (Tremonti and Vitaletti 1994). We can summarise the devolution features in terms of advantages and disadvantages in table 1.

The administrative reforms have followed, more or less, the same guidelines which can be observed in most western countries. For example, a shift towards the separation of political decision making and 
public management, an attempt to introduce a managerial culture focused on results and services to the citizens, the 'privatisation' of the civil service in order to improve the civil servants accountability, the 'contractualisation' of public chief executives during a 2-5 years' tenure. It is here worth mentioning the fragmentation of the public sector apparatus into autonomous or semiautonomous entities, like governmental agencies, health care organisations, etc., as well as the budgeting and accounting reforms, characterised by the problematic adoption of some elements of the accrual concept, and the internal and external control reforms.

Table 1. Devolution features

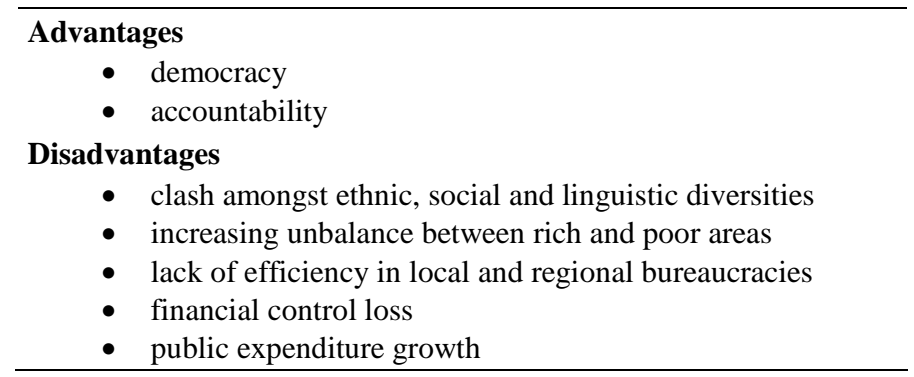

Some relevant issues arise from the above-mentioned considerations, related to the effectiveness of the working accounting, budgeting, and control systems. We can consider two different research questions. The first one regards whether the budgeting and accounting systems have been really reformed in order to fulfil the information needs coming from citizens and governments, and to face the challenges coming from devolution and, possibly, federalism. The second one is whether the control systems have left their exclusive traditional juridical nature to become effective auditing systems. This paper will only concentrate on the first of these two questions.

The first instrumental aim of the paper will be to ascertain if we can speak about an Italian public sector budgeting and accounting model, through the creation of a grid used to compare the different systems, and to shape one or few models from the prevailing features found. The second one will be to evaluate if this (these) model(s) is (are) adequate to sustain the information needs coming from citizens and public management in a decentralised country.

This research has been carried out through: 1) review of the literature on accountability and information needs in the public sector, 2) 
analyses and comparisons of budgeting and accounting rules concerning every Italian public sector category, 3) shaping the model, 4) comparisons between the model informative capacity and the information needs, particularly in a country characterised by a process of power devolution.

The article is divided as follows. Section two presents the theoretical framework; the accountability concept is discussed to explain the relationships that link the different actors - citizens, assemblies, governments, public managers and servants - in a devolved environment. The information citizens need to deliberately choose their representatives and elected managers use to manage public affairs is defined from a rationale point of view. Section three deals with the eleven budgeting and accounting systems that are found in the Italian public sector; their most relevant features are considered and compared. Two accounting models are shaped; the former is mainly related to democratic bodies organisations whose decision making processes start from citizenry electoral choices -, and the latter is related to the instrumental ones. The first is built on a prevailing cash base; the second is underpinned by the accrual concept. Section four compares the information supplied with the needs that come from the devolution disadvantages defined above. The research findings are that this information is not adequate to face the challenges coming from the ongoing devolution process. The Italian case gives evidence that a strong devolution process does not necessarily match with advanced accounting reforms. Further researches will be able to compare the relationships between the degree of powers devolution and the accounting systems features in different countries.

\section{INFORMATION NEEDS}

According to the political foundation of the democratic systems, all citizens are regarded as ethical owners of public resources; being electors, taxpayers, public service users, they are the very centre of public life. Within the framework of the agency theory (Pratt and Zeckhauser 1984; Ross 1973), citizens are considered as the principal with reference to assemblies like parliaments, municipal councils, etc. and, when elected, to governments. The same framework is usually used to explain relationships that link appointed governments to assemblies, and public managers to governments. Because of the usual situation of asymmetry on information and the utilitarian principle claimed by literature on public choice (Mueller 1979; Rowley 1987), the agents' behaviour is not 
obviously aimed to the principals' welfare. In this general setting, the international literature on public sector management and accounting discusses the accountability concept from different points of view (Sinclair 1995; Steccolini 2004). According to the Governmental Accounting Standards Board (GASB 1987: 20-21), to be accountable means "being obliged to explain one's actions, to justify what one does", and "accountability is the cornerstone of all financial reporting in government". In general terms, the accountability concept refers to relational situations in which the agent called accountor - has to give information to the principal - called the accountee - on what he did, how he managed resources, which actions he carried out, and which goals he reached. The latter has a right to be informed and the power to judge the agent's behaviour and to reward or sanction him. The former has the duty, primarily to perform in the principal's interest and in compliance with the stated objectives, and secondly to give the principal satisfying information (Mulgan 2000).

Different codes and channels of accountability are discussed by various authors (Gray and Jenkins 1993; Pezzani 2003; Sinclair 1995). The political accountability relates to relationships between elected officials and citizens; the managerial accountability relates to relationships between assemblies and governments, and between governments and public managers. In a country that both has implemented a public sector accounting reform and is going in the direction of the devolution of powers and possibly a federal form of the State, it is also relevant to take into account the accountability relationships amongst the different levels of governments - government mutual accountability -, necessary to put into practice the public sector general co-ordination (Ongaro 2003).

As for the accounting reform subject, it is worth mentioning that, unlike the business sector, in the public administration practice there are a variety of accounting criteria. We can distinguish the "measurement focus", related to the amount - e.g., equity or cash - the accounting system has to quantify at a certain day and its variation during a certain period, from the basis of accounting, related to the moment in which revenues and expenditures and the related assets and liabilities are recognised (Lüder and J ones 2003: 21; Mead 2001: 5). The criterion choice causes important differences in the accounting systems which can be considered as the main cause of accounting diversities between different countries (Brusca and Condor 2002). The shift from the cash basis to the accrual one usually implies the information focus moving from the budget to the financial statement, and a problematic connection between the previous budget and 
the new financial accounting (Christiaens 2004). In order to define which kind of accounting system is the most suitable, it is necessary to determine who are the subjects involved and what are their information needs.

The reference to the federal form of the state allows us to connect the accountability relationship that links the different levels of governments - i.e. municipalities to central government - with the accounting and budgeting system function in supporting governments' decision making and activity. The public sector accounting information has therefore the double purpose of informing citizens, as electors, taxpayers, ethic owners, customers (Drebin et al. 1981; The International Federation of Accountants Public Sector Committee - IFAC PSC 2000), and supporting governments' mutual accountability and decision making.

From a logic point of view, information that is interesting for the citizens deals first with the amount and quality of tax collection and public expenditure, outcomes, outputs, efficiency, effectiveness, and secondly with what type of interests are supported by the programmes implementation. The correlation between outputs and resources is relevant to understand how much public action costs and who and when must pay for it, and is usually considered in the light of the intergenerational equity ethic principle (Gasb 1987; J ones and Pendlebury 2000: 202; Pavan 2003: 17). Such a principle suggests that the generation which uses the assets and benefits from facilities should pay for them. Accordingly, the accounting system should ensure that every liability, even if only estimated, is timely accounted and disclosed.

The budgeting and accounting systems have also to support governments for the definition of their action for the short and the medium term, and serve as means of spending permission from assemblies. Therefore, governments' activity needs information for both accountability and decision-making. At a more detailed level, a government has to:

- know which is the public net asset and its changes during a period of time in order to evaluate whether it has been preserved, increased or decreased;

- evaluate its ability to finance activities and to meet liabilities and commitments; particularly, a government needs full information on the level, composition and dynamics of debts and financial assets;

- evaluate its performance in terms of service efforts and accomplishments (GASB 1994); 
- be accountable for public resource managing.

In order to promote accountability, the budget and accounts are related to the objectives and results of government activity, rather than simply to the items on which money is spent. Thus, modern budgeting tries to identify, as far as possible, the objectives of government activities and to measure outputs and outcomes in relation to these objectives. A significant element of early efforts in this direction can be found in the classification of expenditure into "program," "subprogram," and "activity" categories, defined with increasing specificity at the more detailed levels in relation to a clearly stated set of objectives ${ }^{1}$ (International Monetary Fund - IMF 2001).

Faced with different alternatives, each country should adopt the budgeting and accounting system suitable for the information needs at the time considered. The citizens and governments information needs are summarised in table 2 .

Table 2. Information needs

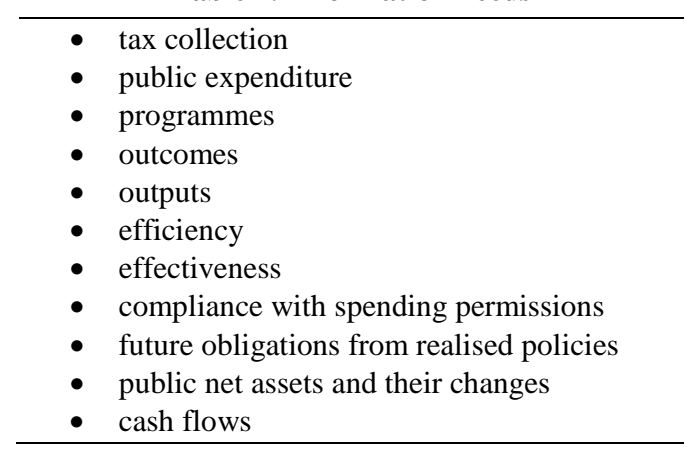

As regards the specific information needs arising out of powers devolving, a first relevant point is that in any system with some degree of decentralisation there is a dual responsibility in allocating decision powers. Unitary states will devolve to lower-tier authorities the administration of central policies if regional and local organisations can assure efficiency benefits; in federal states, the central government may prescribe uniform standards to local authorities or require them to

1 The United States, through its Planning, Programming, and Budgeting System, represented the leading example in the mid-1960s. 
undertake national policies. It is so important to be well aware of the institutional framework quality and of how public expenditures are managed by central and lower-tier governments (Tanzi 2000). A typical feature of a working institutional framework for intergovernmental fiscal relations ${ }^{2}$ is that powers and responsibilities are based "on stable principles and/ or agreed formulae and that they should be clearly stated" (IMF 2001). In short, the contract between central and sub-national governments should be feasible and clear both on revenues and expenditures. A prerequisite for budget co-ordination seems to be the availability of public budgeting and accounting systems with a comprehensive coverage.

In federal states, the importance of providing information on government revenues, expenditures, and borrowing should be stressed exactly when the central government budget is presented. In this relation, standardising statistical presentation seems to be necessary by adopting common revenues and expenditures classifications. Finally, good practices in the field of budget execution and reporting are essential for fiscal stabilisation. Timely and comprehensive reporting is necessary to enable the central government to monitor the financial position of lower-tier governments, in order to be able to detect individual authorities in trouble and call for remedial actions. According to IFAC/PSC studies $(5,6,8,9,11$ and 14), supported with a series of Occasional Papers $(1,3)$ documenting case studies, the information provided by accrual accounting allows users to satisfy their information needs especially in regard to government performance, its financial position and cash flows. At last, we can add that the devolution of financial powers without strong budgeting, accounting and auditing systems might weaken the public finances in a fatal way.

\section{SHAPING THE ITALIAN PUBLIC SECTOR ACCOUNTING MODEL}

The Italian public sector is divided into several organisational categories: the central State as a whole - in the Italian legal system, a single legal entity -, and its organisational entities such as ministries and departments, regions, provinces, municipalities, but also governmental

2 The issue of fiscal co-ordination between different levels of government is topical in the context of the EU Stability and Growth Pact which sets limits to the level of deficit with reference to the national general governments (which includes lower-tier governments) and contrasts with the high degree of fiscal decentralisation. This calls for developing, in each country, some legal or procedural framework - internal stability pact - for ensuring that the fiscal behaviour of regional and local entities is consistent with the European commitments. 
agencies, social securities and health care bodies, schools, publicly owned companies, etc. All these organisations are, in some way, autonomous; every category has a particular budgeting and accounting system defined by laws and regulations. In our research we have distinguished between organisations whose decision making processes start from citizenry electoral choices - hereafter called democratic or electoral bodies -, and those which do not depend directly on electoral choices, but are more often under the control of the former - instrumental bodies.

We have observed eleven Italian public sector organisation categories, whose accounting features are well defined in laws and regulations ${ }^{3}$. They are shown in table 3.

Table 3. The considered Italian public sector organisations

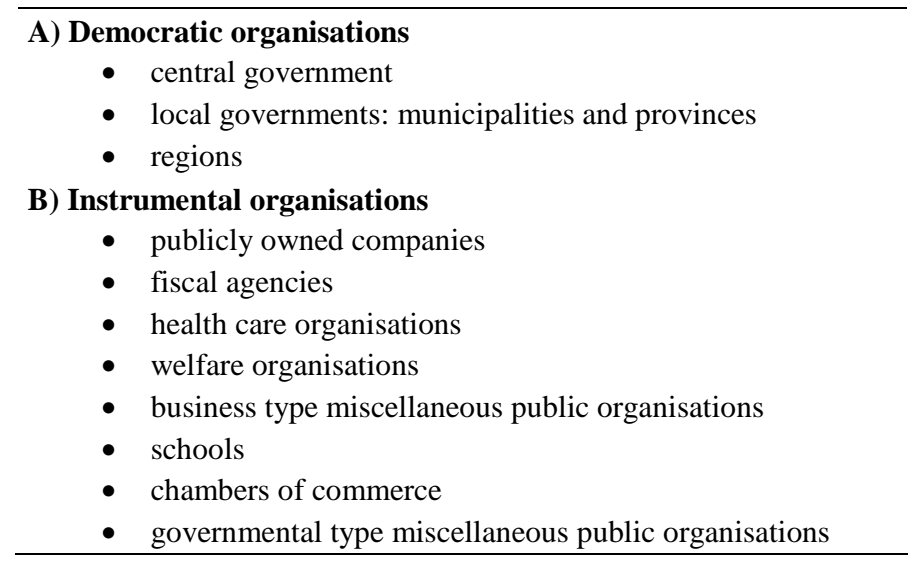

The analysis of the literature on public budgeting and accounting systems (Chan and Xiaoyue 2002; Lüder and Jones 2003; Montesinos and Vela 2002), enables us to focus our discussion on some relevant points such $\mathrm{as}^{4}$ :

- budget nature: whether it is drawn up on a cash, cash and commitment - obligation -, or accrual base;

\footnotetext{
3 We have not considered universities, as there isn't a national accounting law; the budgeting and accounting regulation is devolved to the single entities.

4 Some budget features are drown from OECD classification (OECD - Organisation for Economic Co-operation and Development/ World Bank 2003).
} 
- accounting system: whether the entity adopts a budget accounting on a cash - and commitment - base, or a financial accounting system on an accrual base;

- book-keeping method: whether the accounting system is drawn up using the double-entry method or not;

- reporting statements: whether they are related to the budget or they present the balance sheet, the operating statement, the cash-flow account, the notes to the financial statement, the management discussion statement;

- disclosure: which kind of financial information is presented to citizens and assemblies, and in which way.

In shaping the model we built a double-entry grid, shown on table 4, using the features found in laws and regulations related to the budget and accounting system in every organisation category. In doing this, we tried not to keep to the letter of the law, but undertook a systematic analysis of the single category regulations, considered as a whole, to ascertain if every distinct legal proposition is consistent with the other and if its implementation could be forecast in a rational way.

\section{Democratic organisations}

The democratic organisation category consists of central, local - mainly municipal - and regional governments. Budget, accounting and finance rules in local governments were defined in essence, as they are now, in 1995 - D. Lgs. N 77/ 1995 -, and again in 2000 - D. Lgs. $n^{\circ}$ 267/ 2000. Moreover, we have considered some other rules and explanations derived from a few decrees - e.g., D.P.R. n 194/ 1996 - and memorandums issued by the Ministry of Domestic Affairs.

The rules about the central government budget, accounting and finance are very complex and derive from several laws, decrees and memorandums, issued since the 1920s. In 1997 - L. n 94/ 1997 - a relevant reform process was begun, changing some provisions in the body of the main law n. 468/1978. As we have just one entity in this category, we have also considered the budget for the year 2003, the balance sheet and the budget accounting statement for the year 2001. 
The 1948 Italian Constitutional Act provides for two kinds of regions, with an ordinary or a special statute. In any case, the single region has the power to issue specific budget, accounting and finance rules; in our research, we have considered just the general framework, related to ordinary statute regions, which comes from the D. Lgs. $n^{\circ} 76 / 2000$.

The central government. Traditionally, the Italian central State has adopted an information system focused on a budget drawn on both a commitment - when the spending decision is made and the juridical obligation undertaken - and a cash base. The accounting system was only related to the budget spending permission; there was no financial accounting. An annual balance sheet was prepared, but simply using figures coming from the budget accounting and inventories; in fact, for decades little regard was shown for the correct and comprehensive drawing of this statement and little attention was paid for its use. With the reform law $n$. 94/ 1997 the budget is divided according not only to ministries, but also to organisational units; moreover, central administrations have to adopt a management accounting system (Caperchione and Mussari 2002; Pavan and Reginato 2004: 312). Consequently, specific budget and accounts defined on an accrual base are prepared; they don't have to be approved by Parliament, but the budget is presented to the two elected assemblies just for a general reading (Conte 1999; Pacifico 1999). We have to observe here that the figures in input in the mentioned system come from the budget accounting, and have to be reconciled from the commitment to the accrual base. As a reliable balance sheet wasn't available, depreciations are considered just for fixed assets bought in 2000 and following years. No provisions are considered.

In a more formal way, we can now observe a budget and a set of accounts drawn on the accrual base, analytically related to the organisational units. A relevant issue here asks which are the right answers to the questions, presented in the grid, concerning the type of appropriation and the accounting system. With regard to 1.1 in table 4, we observe that so far we have no pro-forma balance sheet, no operating statement, but just the same figures coming from the budget on the commitment base, reconciled to indicate when and in which organisational unit resources are used. Thus, it isn't possible to assert that a resource budgeting and an "accrual-based" type of appropriation in a wide sense are in use (Lüder and J ones 2003: 35). As regards 2.1, the positive answer to the question related to the management accounting system is worth noticing. The reason is that we have a set of accounts analytically related to the organisational 
units on an accrual base, even if they are not comprehensive and probably not completely reliable.

Table 4. The grid - Democratic organisations

\begin{tabular}{|c|c|c|c|c|}
\hline & 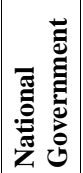 & 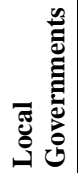 & 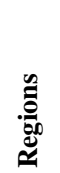 & 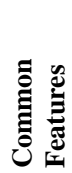 \\
\hline \multicolumn{5}{|l|}{ 1. Budgeting } \\
\hline \multicolumn{5}{|l|}{ 1.1. Type of appropriation } \\
\hline Commitment (or Obligation) based & $\mathrm{X}$ & $\mathrm{X}$ & $\mathrm{X}$ & $\mathrm{X}$ \\
\hline Cash based & $\mathrm{X}$ & & $\mathrm{X}$ & \\
\hline \multicolumn{5}{|l|}{ Accrual based } \\
\hline \multicolumn{5}{|l|}{ 1.2. Documents } \\
\hline Annual budget & $\mathrm{X}$ & $\mathrm{X}$ & $\mathrm{X}$ & $\mathrm{X}$ \\
\hline Multi-year budget & $\mathrm{X}$ & $\mathrm{X}$ & $\mathrm{X}$ & $\mathrm{X}$ \\
\hline Forecasting management descriptive documents & $\mathrm{X}$ & $\mathrm{X}$ & $\mathrm{X}$ & $\mathrm{X}$ \\
\hline \multicolumn{5}{|l|}{ 1.3. Expenditures classification } \\
\hline Function (e.g. defense, health, education) & $\mathrm{X}$ & $\mathrm{X}$ & $\mathrm{X}$ & $\mathrm{X}$ \\
\hline Economic classification (e.g. interest, grants, employee compensation) & $\mathrm{X}$ & $\mathrm{X}$ & $\mathrm{X}$ & $\mathrm{X}$ \\
\hline Capital/current expenditure breakdown (as part of line-item classification) & $\mathrm{X}$ & $\mathrm{X}$ & $\mathrm{X}$ & $\mathrm{X}$ \\
\hline $\begin{array}{l}\text { Administrative classification, or by organisation (e.g. hierarchical levels and } \\
\text { administrative units in line ministries) }\end{array}$ & $\mathrm{X}$ & $\mathrm{X}$ & $\mathrm{X}$ & $\mathrm{X}$ \\
\hline $\begin{array}{l}\text { Programme classification reflecting the government's policy objectives and } \\
\text { individual programme budgets }\end{array}$ & & $\mathrm{X}$ & & \\
\hline \multicolumn{5}{|l|}{ 1.4. Functions } \\
\hline Political & $\mathrm{X}$ & $\mathrm{X}$ & $\mathrm{X}$ & $\mathrm{X}$ \\
\hline Authorization & $\mathrm{X}$ & $\mathrm{X}$ & $\mathrm{X}$ & $\mathrm{X}$ \\
\hline Steering and programming & $\mathrm{X}$ & $\mathrm{X}$ & $\mathrm{X}$ & $\mathrm{X}$ \\
\hline \multicolumn{5}{|l|}{ 1.5. Types of performance targets included in the budget process } \\
\hline Outputs & & $\mathrm{X}$ & & \\
\hline \multicolumn{5}{|l|}{ Outcomes } \\
\hline \multicolumn{5}{|l|}{ Combination of outputs and outcome } \\
\hline \multicolumn{5}{|l|}{ 2. Accounting } \\
\hline \multicolumn{5}{|l|}{ 2.1. Accounting systems } \\
\hline Budget accounting & $\mathrm{X}$ & $\mathrm{X}$ & $\mathrm{X}$ & $\mathrm{X}$ \\
\hline \multicolumn{5}{|l|}{ Financial accounting } \\
\hline Management accounting & $\mathrm{X}$ & & $\mathrm{X}$ & \\
\hline \multicolumn{5}{|l|}{ 2.2. Bases of accounting } \\
\hline Commitment (or Obligation) based & $\mathrm{X}$ & $\mathrm{X}$ & $\mathrm{X}$ & $\mathrm{X}$ \\
\hline Cash based & 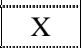 & & $\mathrm{X}$ & \\
\hline Accrual based & & $\mathrm{X}$ & & \\
\hline \multicolumn{5}{|l|}{ 2.3. Book-keeping method } \\
\hline Single-entry & $\mathrm{X}$ & $\mathrm{X}$ & $\mathrm{X}$ & $\mathrm{X}$ \\
\hline Double-entry & & & & \\
\hline
\end{tabular}




\begin{tabular}{|c|c|c|c|c|}
\hline \multicolumn{5}{|l|}{ 3. Reporting and disclosure } \\
\hline \multicolumn{5}{|l|}{ 3.1. Reporting documents } \\
\hline Budgetary statement & $X$ & $\mathrm{X}$ & $X$ & $\mathrm{X}$ \\
\hline Balance sheet & $\mathrm{X}$ & $\mathrm{X}$ & $\mathrm{X}$ & $\mathrm{X}$ \\
\hline Operating statement & & $\mathrm{X}$ & & \\
\hline \multicolumn{5}{|l|}{ Notes to the financial statement } \\
\hline Management discussion statement & & $\mathrm{X}$ & & \\
\hline \multicolumn{5}{|l|}{ Cash-flow statement } \\
\hline \multicolumn{5}{|l|}{ 3.2. Compulsory publication } \\
\hline National and local press & & $\mathrm{X}$ & & \\
\hline Official Gazette & $\mathrm{X}$ & & $\mathrm{X}$ & \\
\hline Local notice board & & $\mathrm{X}$ & & \\
\hline \multicolumn{5}{|l|}{ Register of companies } \\
\hline \multicolumn{5}{|l|}{ 3.3. User-friendly publication } \\
\hline \multicolumn{5}{|l|}{ Yes } \\
\hline None & $X$ & $X$ & $X$ & $X$ \\
\hline
\end{tabular}

Local governments. The 1995 budgeting, accounting and finance regulations for local governments are focused on a budget drawn on a commitment base. The accounting system is related only to the budget spending permission. Municipalities have to present an annual balance sheet and an operating statement, however their figures do not come from a double-entry accounting system, but from the budget accounting. A specific statement is devoted to reconcile the figures from the commitment base to the accrual one. As we do not have a proper financial accounting system, in our grid we give a negative answer to the related question in 2.1. The answer to the same point 2.1 about management accounting is also a negative one. The letter of the law deals with the adoption of a managerial accounting system and a set of output objectives. In fact, the figure reconciliation from the commitment to the accrual base is carried out just once a year and in a general - not analytical - way. Thus we wonder how it is possible to measure the single organisational unit efficiency if we have no accrual analytical figures to compare with the actual outputs.

Regional governments. At the general analysis level here adopted, regional governments' budgeting and accounting features present no relevant differences from the central State.

As regards democratic bodies, a common feature is related to the disclosure issue; in every category the grid shows only compulsory publications. Obviously, we can't say that what isn't in the law is forbidden, but in the analysed regulations we didn't find a clear evidence of the advisability of presenting to people an user-friendly information. It's here worth mentioning that local governments have to publish a synthesis of 
their accounts on newspapers according to a law whose heading is about financial aids to editorial companies!

Instrumental organisations

As it is shown in table 3, we have considered eight instrumental organisation categories. It is not so easy to understand if they have to be considered as a whole, or if there are some other features of interest for our research purposes, and according to which we can find a classification criterion. In the first place we could consider whether revenues come mainly from payments for the selling of services business-type entities - or from tax levying and grants from other public bodies - governmental-type entities. As our research is focused on accounting regulations, it is not easy to distinguish the former from the latter. Companies publicly owned, for instance, are clearly devoted to the market, while fiscal agencies are rewarded on a contractual base by the government, and health care bodies are both rewarded on a contractual base and by grants. This kind of criterion could be possibly used, on a statistical base, in a research focused on financial statements. Secondly, we can provide an analysis of the organisation categories using our grid and just wait to see if it is possible to group entities according to common features arisen out of the analysis.

Following this path, the analysis shows two instrumental organisation groups; the first includes five categories, while the second three (see table 5). In the former - business-type entities - we find features such as the budget and the accounting ones on an accrual base, the double-entry book-keeping method, and the financial statement (see table 6). In the latter - governmental-type entities - we find features such as the budget and the accounting ones on a commitment base, the singleentry book-keeping method, and the budgetary statement (see table 7).

Table 5. Instrumental organisations

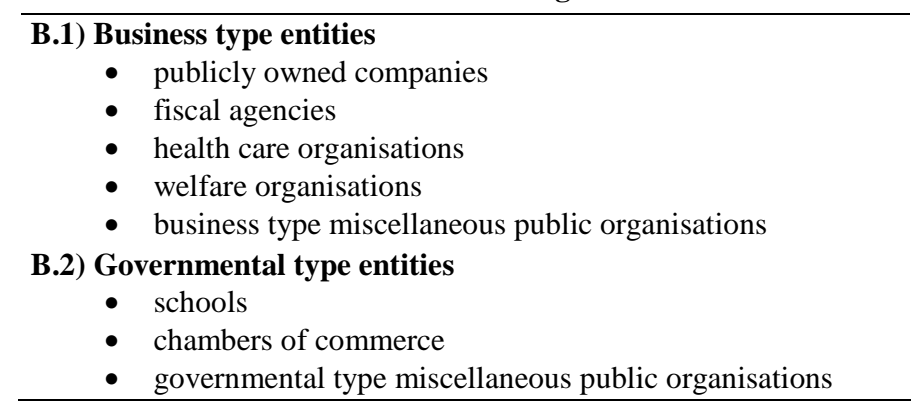


Companies owned by public bodies. Public organisations which sell their products on the market have usually become limited companies (Mele 2003). According to the Italian Civil Code, limited companies have to publish the balance sheet, the operating statement, a data explanatory statement - i.e. notes to the financial statement -, and a management discussion statement. In general practice we find a resource budget, a managerial accounting, a double-entry financial accounting system. The cash-flow statement is not compulsory and not often prepared. The financial statement, and not the budget, is published on the Register of Companies.

Fiscal agencies refer to limited companies rules; the budget is both on an accrual and a cash base and has an authorisation function; general regulations do not provide for managerial accounting, not even for any kind of publication.

Health care, Welfare ${ }^{5}$ and Business-type miscellaneous public organisations ${ }^{6}$ also refer to limited companies rules. As for the health care bodies, the national law states the general accounting principles and devolves powers to the regions to define the analytical rules; so we have now twenty budgeting and accounting systems, as many as the present Italian regions. As for the Welfare and Business-type organisations, no publication at all is provided.

As it is shown in table 8 , the above considered organisations differ from the democratic ones mainly because the related regulations provide first for a budget on an accrual base, without a formal authorisation function, and secondly for an accounting system drawn up by the double-entry book-keeping method; no budget accounting is provided; the reporting document is the financial statement.

Up to now, the analysis has shown that democratic bodies have an accounting model based on the traditional cash and commitment base, while the considered instrumental organisations use a business-type accounting model. The analysis of the remaining public bodies shows a hybrid situation, (see table 7).

\footnotetext{
6 Organisations whose revenues come mainly from the selling of services, such as the National Statistical Body - ISTAT - and the Securities Commission - CONSOB. See D. Lgs. 419, October $29^{\text {th }} 1999$.
}

$4^{\text {th }} 2001$

5 Aziende Pubbliche di Servizi alla Persona, APSP ex IPAB. See D. Lgs. 207, May 
Table 6. The grid - Business type instrumental organisations

\begin{tabular}{|c|c|c|c|c|c|c|}
\hline & 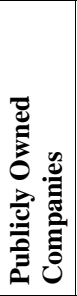 & 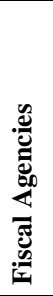 & 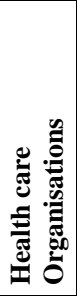 & 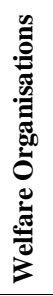 & 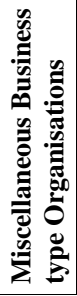 & 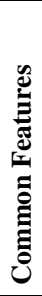 \\
\hline \multicolumn{7}{|l|}{ 1. Budgeting } \\
\hline \multicolumn{7}{|l|}{ 1.1. Type of appropriation } \\
\hline \multicolumn{7}{|l|}{ Commitment (or Obligation) based } \\
\hline Cash based & & $\mathrm{X}$ & & & & \\
\hline Accrual based & $\mathrm{X}$ & $\mathrm{X}$ & $\mathrm{X}$ & $\mathrm{X}$ & $\mathrm{X}$ & $\mathrm{X}$ \\
\hline \multicolumn{7}{|l|}{ 1.2. Documents } \\
\hline Annual budget & $\mathrm{X}$ & $\mathrm{X}$ & $\mathrm{X}$ & $\mathrm{X}$ & $\mathrm{X}$ & $\mathrm{X}$ \\
\hline Multi-year budget & $\mathrm{X}$ & & $\mathrm{X}$ & $\mathrm{X}$ & $\mathrm{X}$ & \\
\hline \multicolumn{7}{|l|}{ Forecasting management descriptive documents } \\
\hline \multicolumn{7}{|l|}{ 1.3. Expenditures classification } \\
\hline \multicolumn{7}{|l|}{ Function (e.g. defense, health, education) } \\
\hline $\begin{array}{l}\text { Economic classification (e.g. interest, grants, employee } \\
\text { compensation) }\end{array}$ & $\mathrm{X}$ & $\mathrm{X}$ & $X$ & $\mathrm{X}$ & $X$ & $\mathrm{X}$ \\
\hline $\begin{array}{l}\text { Capital/current expenditure breakdown (as part of line-item } \\
\text { classification) }\end{array}$ & $\mathrm{X}$ & $\mathrm{X}$ & $\mathrm{X}$ & $\mathrm{X}$ & $\mathrm{X}$ & $X$ \\
\hline $\begin{array}{l}\text { Administrative classification, or by organisation (e.g. hierarchical } \\
\text { levels and administrative units in line ministries) }\end{array}$ & $\mathrm{X}$ & & $\mathrm{X}$ & $\mathrm{X}$ & $\mathrm{X}$ & \\
\hline \multicolumn{7}{|l|}{$\begin{array}{l}\text { Programme classification reflecting the government's policy } \\
\text { objectives and individual programme budgets }\end{array}$} \\
\hline \multicolumn{7}{|l|}{ 1.4. Functions } \\
\hline \multicolumn{7}{|l|}{ Political } \\
\hline Authorization & & $\mathrm{X}$ & & & & \\
\hline Steering and programming & $\mathrm{X}$ & $\mathrm{X}$ & $\mathrm{X}$ & $\mathrm{X}$ & $\mathrm{X}$ & $\mathrm{X}$ \\
\hline \multicolumn{7}{|l|}{ 1.5. Types of performance targets included in the budget process } \\
\hline \multicolumn{7}{|l|}{ Outputs } \\
\hline \multicolumn{7}{|l|}{ Outcomes } \\
\hline \multicolumn{7}{|l|}{ Combination of outputs and outcome } \\
\hline \multicolumn{7}{|l|}{ 2. Accounting } \\
\hline \multicolumn{7}{|l|}{ 2.1. Accounting systems } \\
\hline \multicolumn{7}{|l|}{ Budget accounting } \\
\hline Financial accounting & $\mathrm{X}$ & $\mathrm{X}$ & $\mathrm{X}$ & $\mathrm{X}$ & $\mathrm{X}$ & $\mathrm{X}$ \\
\hline Management accounting & $\mathrm{X}$ & & $\mathrm{X}$ & $\mathrm{X}$ & $\mathrm{X}$ & \\
\hline \multicolumn{7}{|l|}{ 2.2. Bases of accounting } \\
\hline \multicolumn{7}{|l|}{ Commitment (or Obligation) based } \\
\hline \multicolumn{7}{|l|}{ Cash based } \\
\hline Accrual based & $\mathrm{X}$ & $\mathrm{X}$ & $\mathrm{X}$ & $\mathrm{X}$ & $\mathrm{X}$ & $\mathrm{X}$ \\
\hline \multicolumn{7}{|l|}{ 2.3. Book-keeping method } \\
\hline \multicolumn{7}{|l|}{ Single-entry } \\
\hline Double-entry & $\mathrm{X}$ & $\mathrm{X}$ & $\mathrm{X}$ & $\mathrm{X}$ & $\mathrm{X}$ & $\mathrm{X}$ \\
\hline
\end{tabular}




\begin{tabular}{|c|c|c|c|c|c|c|}
\hline \multicolumn{7}{|l|}{ 3. Reporting and disclosure } \\
\hline \multicolumn{7}{|l|}{ 3.1. Reporting documents } \\
\hline \multicolumn{7}{|l|}{ Budgetary statement } \\
\hline Balance sheet & $\mathrm{X}$ & $\mathrm{X}$ & $\mathrm{X}$ & $\mathrm{X}$ & $\mathrm{X}$ & $\mathrm{X}$ \\
\hline Operating statement & $\mathrm{X}$ & $\mathrm{X}$ & $\mathrm{X}$ & $\mathrm{X}$ & $\mathrm{X}$ & $\mathrm{X}$ \\
\hline Notes to the financial statement & $\mathrm{X}$ & $\mathrm{X}$ & $\mathrm{X}$ & $\mathrm{X}$ & $\mathrm{X}$ & $\mathrm{X}$ \\
\hline Management discussion statement & $\mathrm{X}$ & $\mathrm{X}$ & $\mathrm{X}$ & $\mathrm{X}$ & $\mathrm{X}$ & $\mathrm{X}$ \\
\hline \multicolumn{7}{|l|}{ Cash-flow statement } \\
\hline \multicolumn{7}{|l|}{ 3.2. Compulsory publication } \\
\hline \multicolumn{7}{|l|}{ National and local press } \\
\hline \multicolumn{7}{|l|}{ Official Gazette } \\
\hline Local notice board & & & $\mathrm{X}$ & & & \\
\hline Register of companies & $\mathrm{X}$ & & & & & \\
\hline \multicolumn{7}{|l|}{ 3.3. User-friendly publication } \\
\hline \multicolumn{7}{|l|}{ Yes } \\
\hline None & $\mathrm{X}$ & $\mathrm{X}$ & $\mathrm{X}$ & $\mathrm{X}$ & $\mathrm{X}$ & $\mathrm{X}$ \\
\hline
\end{tabular}

Schools refer to the democratic organisations accounting model. The budget and the accounting systems are on a commitment base; the former has a formal authorisation function; the book-keeping method is the single-entry one; the main reporting document is the budgetary statement; no publication is provided.

Chambers of commerce. The budget is drawn up on a commitment base and has a formal authorisation function. The accounting system is both on an accrual and a commitment base; the book-keeping method is the double-entry one. As for the reporting documents, we find both budgetary and financial statements; no publication is provided.

Governmental-type miscellaneous public bodies. The accounting regulations issued in $2003^{7}$ considers a very important group of public bodies not devoted to the market. Among others, the social security bodies are worth mentioning here, and particularly the Istituto Nazionale della Previdenza Sociale (INPS - Social Security National Body), whose budget is the second in amount in the Italian public sector, after the central State one. The accounting legal system under consideration is relevant also because it comes last in the accounting reform process. As for the State, the budget is drawn up on a commitment and a cash base. An accrual-based budget is also provided; yet, as it includes just the proforma operating statement and not the balance sheet, we could not 
answer positively to the related question in the grid. According to an obscure logic, rules request a complete financial statement - balance sheet, operating statement and the related notes -, but the book-keeping method provided is the single-entry one.

The Italian accounting model

On the bases of the grid showed on table 8 it is possible to state that there isn't a single Italian public sector accounting model. As a matter of fact, the features common to all organisation categories are very few - just six - and certainly inadequate, from a qualitative point of view, to shape an accounting model. On the contrary, we can recognise two different sets of accounting features: the first relates to the democratic organisations and affects the governmental-type instrumental bodies very heavily - just five differences found -; the second relates to the businesstype instrumental bodies. The latter makes up a business-like model. Our attention hereafter is put on the former, due to the direct link with the citizens' electoral choice.

The democratic organisations accounting model is made up of the common features of the three categories, shown in the fourth column, table 4. The budget, prepared on a commitment base, is both annual and multi-year, and is accompanied by a forecasting-managementdescriptive document. The expenditures are classified into: functional, economic, capital/current, and organisational categories; there are neither programme classifications, nor generalised performance measures. Political, authorisation, steering and programming functions are present.

The accounting system in use is the budget one; the base of accounting is set on a commitment - or obligation - base, focused on the budget and the rules concerning spending permissions; the double-entry book-keeping is not in use.

Table 7. The grid - Governmental type instrumental organisations

\begin{tabular}{|c|c|c|c|c|}
\hline & $\begin{array}{l}\frac{n}{0} \\
\frac{\mathscr{g}}{\tilde{n}} \\
\tilde{n}\end{array}$ & 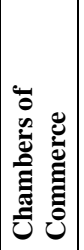 & 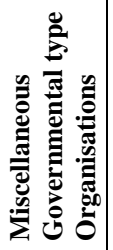 & 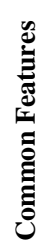 \\
\hline \multicolumn{5}{|l|}{ 1. Budgeting } \\
\hline 1.1. Type of appropriation & & & & \\
\hline
\end{tabular}




\begin{tabular}{|c|c|c|c|c|}
\hline Commitment (or Obligation) based & $\mathrm{X}$ & $\mathrm{X}$ & $X$ & $\mathrm{X}$ \\
\hline Cash based & & & $\mathrm{X}$ & \\
\hline \multicolumn{5}{|l|}{ Accrual based } \\
\hline \multicolumn{5}{|l|}{ 1.2. Documents } \\
\hline Annual budget & $\mathrm{X}$ & $\mathrm{X}$ & $\mathrm{X}$ & $\mathrm{X}$ \\
\hline Multi-year budget & & & $\mathrm{X}$ & \\
\hline Forecasting management descriptive documents & $\mathrm{X}$ & $\mathrm{X}$ & $\mathrm{X}$ & X \\
\hline \multicolumn{5}{|l|}{ 1.3. Expenditures classification } \\
\hline Function (e.g. defense, health, education) & & & $\mathrm{X}$ & \\
\hline Economic classification (e.g. interest, grants, employee compensation) & $\mathrm{X}$ & $\mathrm{X}$ & $\mathrm{X}$ & $\mathrm{X}$ \\
\hline Capital/current expenditure breakdown (as part of line-item classification) & $\mathrm{X}$ & X & $\mathrm{X}$ & $\mathrm{X}$ \\
\hline $\begin{array}{l}\text { Administrative classification, or by organisation (e.g. hierarchical levels and } \\
\text { administrative units in line ministries) }\end{array}$ & & $\mathrm{X}$ & $\mathrm{X}$ & \\
\hline $\begin{array}{l}\text { Programme classification reflecting the government's policy objectives and } \\
\text { individual programme budgets }\end{array}$ & $\mathrm{X}$ & & & \\
\hline \multicolumn{5}{|l|}{ 1.4. Functions } \\
\hline Political & & & $\mathrm{X}$ & \\
\hline Authorization & $\mathrm{X}$ & 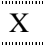 & X & $\mathrm{X}$ \\
\hline Steering and programming & $\mathrm{X}$ & X & $\mathrm{X}$ & $\mathrm{X}$ \\
\hline \multicolumn{5}{|l|}{ 1.5. Types of performance targets included in the budget process } \\
\hline Outputs & & & $\mathrm{X}$ & \\
\hline \multicolumn{5}{|l|}{ Outcomes } \\
\hline \multicolumn{5}{|l|}{ Combination of outputs and outcome } \\
\hline \multicolumn{5}{|l|}{ 2. Accounting } \\
\hline \multicolumn{5}{|l|}{ 2.1. Accounting systems } \\
\hline Budget accounting & $\mathrm{X}$ & $\mathrm{X}$ & $\mathrm{X}$ & $\mathrm{X}$ \\
\hline Financial accounting & & X & & \\
\hline Management accounting & & $\mathrm{X}$ & $\mathrm{X}$ & \\
\hline \multicolumn{5}{|l|}{ 2.2. Bases of accounting } \\
\hline Commitment (or Obligation) based & $\mathrm{X}$ & 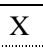 & $\mathrm{X}$ & $\mathrm{X}$ \\
\hline Cash based & & & $\mathrm{X}$ & \\
\hline Accrual based & & $\mathrm{X}$ & $\mathrm{X}$ & \\
\hline \multicolumn{5}{|l|}{ 2.3. Book-keeping method } \\
\hline Single-entry & $\mathrm{X}$ & & $\mathrm{X}$ & \\
\hline Double-entry & & X & & \\
\hline \multicolumn{5}{|l|}{ 3. Reporting and disclosure } \\
\hline \multicolumn{5}{|l|}{ 3.1. Reporting documents } \\
\hline Budgetary statement & $\mathrm{X}$ & $\mathrm{X}$ & $\mathrm{X}$ & $\mathrm{X}$ \\
\hline Balance sheet & $\mathrm{X}$ & X & $\mathrm{X}$ & $\mathrm{X}$ \\
\hline Operating statement & & $X$ & $X$ & \\
\hline Notes to the financial statement & & $\mathrm{X}$ & $\mathrm{X}$ & \\
\hline Management discussion statement & & $\mathrm{X}$ & $\mathrm{X}$ & \\
\hline \multicolumn{5}{|l|}{ Cash-flow statement } \\
\hline \multicolumn{5}{|l|}{ 3.2. Compulsory publication } \\
\hline \multicolumn{5}{|l|}{ National and local press } \\
\hline \multicolumn{5}{|l|}{ Official Gazette } \\
\hline \multicolumn{5}{|l|}{ Local notice board } \\
\hline Register of companies & & & & \\
\hline
\end{tabular}




\begin{tabular}{|c|c|c|c|c|c|}
\hline 3.3. User-friendly publication & & & \\
\hline Yes & & $\mathrm{X}$ & $\mathrm{X}$ & $\mathrm{X}$ & $\mathrm{X}$ \\
\hline None
\end{tabular}

Table 8. The grid - General comparison

\begin{tabular}{|c|c|c|c|c|c|}
\hline & 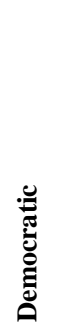 & 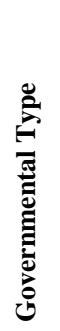 & 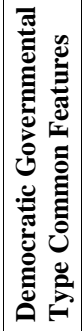 & 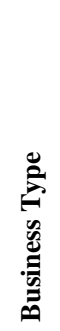 & 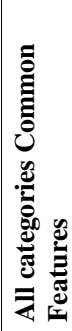 \\
\hline \multicolumn{6}{|l|}{ 1. Budgeting } \\
\hline \multicolumn{6}{|l|}{ 1.1. Type of appropriation } \\
\hline Commitment (or Obligation) based & $\mathrm{X}$ & $\mathrm{X}$ & $\mathrm{X}$ & & \\
\hline \multicolumn{6}{|l|}{ Cash based } \\
\hline Accrual based & & & & $\mathrm{X}$ & \\
\hline \multicolumn{6}{|l|}{ 1.2. Documents } \\
\hline Annual budget & $\mathrm{X}$ & $\mathrm{X}$ & $\mathrm{X}$ & $\mathrm{X}$ & $\mathrm{X}$ \\
\hline Multi-year budget & $\mathrm{X}$ & & & & \\
\hline Forecasting management descriptive documents & $\mathrm{X}$ & $\mathrm{X}$ & $\mathrm{X}$ & & \\
\hline \multicolumn{6}{|l|}{ 1.3. Expenditures classification } \\
\hline Function (e.g. defense, health, education) & $\mathrm{X}$ & & & & \\
\hline Economic classification (e.g. interest, grants, employee compensation) & $\mathrm{X}$ & $\mathrm{X}$ & $\mathrm{X}$ & $\mathrm{X}$ & $\mathrm{X}$ \\
\hline $\begin{array}{l}\text { Capital/current expenditure breakdown (as part of line-item } \\
\text { classification) }\end{array}$ & $\mathrm{X}$ & $\mathrm{X}$ & $\mathrm{X}$ & $\mathrm{X}$ & $\mathrm{X}$ \\
\hline $\begin{array}{l}\text { Administrative classification, or by organisation (e.g. hierarchical levels } \\
\text { and administrative units in line ministries) }\end{array}$ & $\mathrm{X}$ & & & & \\
\hline \multicolumn{6}{|l|}{$\begin{array}{l}\text { Programme classification reflecting the government's policy objectives } \\
\text { and individual programme budgets }\end{array}$} \\
\hline \multicolumn{6}{|l|}{ 1.4. Functions } \\
\hline Political & $\mathrm{X}$ & & & & \\
\hline Authorization & $\mathrm{X}$ & $\mathrm{X}$ & $\mathrm{X}$ & & \\
\hline Steering and programming & $\mathrm{X}$ & $\mathrm{X}$ & $\mathrm{X}$ & $\mathrm{X}$ & $\mathrm{X}$ \\
\hline \multicolumn{6}{|l|}{ 1.5. Types of performance targets included in the budget process } \\
\hline \multicolumn{6}{|l|}{ Outputs } \\
\hline \multicolumn{6}{|l|}{ Outcomes } \\
\hline \multicolumn{6}{|l|}{ Combination of outputs and outcome } \\
\hline \multicolumn{6}{|l|}{ 2. Accounting } \\
\hline \multicolumn{6}{|l|}{ 2.1. Accounting systems } \\
\hline Budget accounting & $\mathrm{X}$ & $\mathrm{X}$ & $\mathrm{X}$ & & \\
\hline Financial accounting & & & & $\mathrm{X}$ & \\
\hline \multicolumn{6}{|l|}{ Management accounting } \\
\hline \multicolumn{6}{|l|}{ 2.2. Bases of accounting } \\
\hline Commitment (or Obligation) based & $\mathrm{X}$ & $\mathrm{X}$ & $\mathrm{X}$ & & \\
\hline \multicolumn{6}{|l|}{ Cash based } \\
\hline Accrual based & & & & $\mathrm{X}$ & \\
\hline
\end{tabular}




\begin{tabular}{|c|c|c|c|c|c|}
\hline \multicolumn{6}{|l|}{ 2.3. Book-keeping method } \\
\hline Single-entry & $\mathrm{X}$ & & & & \\
\hline Double-entry & & & & $\mathrm{X}$ & \\
\hline \multicolumn{6}{|l|}{ 3. Reporting and disclosure } \\
\hline \multicolumn{6}{|l|}{ 3.1. Reporting documents } \\
\hline Budgetary statement & $\mathrm{X}$ & $\mathrm{X}$ & $\mathrm{X}$ & & \\
\hline Balance sheet & $\mathrm{X}$ & $\mathrm{X}$ & $\mathrm{X}$ & $\mathrm{X}$ & $\mathrm{X}$ \\
\hline Operating statement & & & & $\mathrm{X}$ & \\
\hline Notes to the financial statement & & & & $\mathrm{X}$ & \\
\hline Management discussion statement & & & & $\mathrm{X}$ & \\
\hline \multicolumn{6}{|l|}{ Cash-flow statement } \\
\hline \multicolumn{6}{|l|}{ 3.2. Compulsory publication } \\
\hline \multicolumn{6}{|l|}{ National and local press } \\
\hline \multicolumn{6}{|l|}{ Official Gazette } \\
\hline \multicolumn{6}{|l|}{ Local notice board } \\
\hline \multicolumn{6}{|l|}{ Register of companies } \\
\hline \multicolumn{6}{|l|}{ 3.3. User-friendly publication } \\
\hline \multicolumn{6}{|l|}{ Yes } \\
\hline None & $\mathrm{X}$ & $\mathrm{X}$ & $\mathrm{X}$ & $\mathrm{X}$ & $\mathrm{X}$ \\
\hline
\end{tabular}

The budgetary statement is the main reporting document; the balance sheet is also present, but as it doesn't come from a doubleentry accounting system, it is not fully reliable and relevant in practice. The disclosure, in different forms, is only the compulsory one. No userfriendly publications were found; the accounting statements seem to be mysterious to the citizens and, probably, to a lot of elected officials.

\section{CONCLUSIONS}

In our research we have found two budgeting and accounting models through the analysis of eleven different systems. In fact, the Italian public sector accounting systems are many more as the twenty regions have the power to define the accounting rules of their own and of some other organisation categories, such as health care bodies. As a first result, we can advance the hypothesis that the above-noticed regulation variety could be a cause of confusion. With this in mind, we can mention that in the USA, such an old federation, the GASB has issued an accounting principle - n. 34 - aimed at standardising the financial statements of all American public bodies (GASB 1999).

As the business-type accounting model is related to instrumental organisations more or less devoted to the market, the democratic bodies model lies at the very centre of the public sector and 
therefore seems to be much more useful to understand if the Italian public sector could be able to face the challenges coming from the devolution of powers.

Table 2 shows us the information needs to be met by a budget and accounting system. According to table 1, the devolution of financial powers to lower-tier governments presents several relevant disadvantages to be coped with. If we now compare the above-mentioned tables with the democratic organisation accounting model, we can argue what follows.

The clash amongst ethnic, social, and linguistic diversities, and the increasing unbalance between rich and poor areas need good programming and outcomes, outputs and effectiveness measuring. The lack of efficiency in local and regional bureaucracies needs a good efficiency measuring. The financial control loss and the public expenditure growth need future obligations from realised policies, public net assets, tax collection, public expenditure, compliance with spending permissions, and cash flow control.

With reference to the above discussion, we can build a table to compare the information supplied by the Italian model with the information needs, keeping in mind the devolution features. In table 9 we see that the only information provided is related to tax collection, public expenditure and compliance with spending permission. If we consider the budget accounting on a commitment base as a proxy of the cash flow statement, we can include, at large, also this information. The model doesn't present information on programmes and performance measures. The information on assets, liabilities and equity is poor, unclear and unreliable.

After a decade of institutional and administrative reforms the Italian public sector is far from having reached a satisfactory and consistent general order. The many information needs coming from the ongoing devolution process seem not to have been matched by the accounting reforms, whereas the degree of information asymmetry is probably growing. The accounting information is not in compliance with the working devolution process and the transition to the federal form of the State. The risk of significant entropy phenomena is high, as public finances in a devolved or federal country would need stronger accounting systems. 
Table 9. Information needs and supply

\begin{tabular}{|c|c|c|}
\hline Devolution disadvantages & Information needs & $\begin{array}{l}\text { Information supplied } \\
\text { by the model }\end{array}$ \\
\hline \multirow{4}{*}{$\begin{array}{l}\text { - Clash amongst ethnic, social, and } \\
\text { linguistic diversities } \\
\text { - Increasing unbalance between rich and } \\
\text { poor areas }\end{array}$} & - Programmes & None \\
\hline & - Outcomes & None \\
\hline & - Outputs & None \\
\hline & - Effectiveness & None \\
\hline $\begin{array}{l}\text { - Lack of efficiency in local and regional } \\
\text { bureaucracies }\end{array}$ & - Efficiency & None \\
\hline \multirow{6}{*}{$\begin{array}{l}\text { - Financial control loss } \\
\text { - Public expenditure growth }\end{array}$} & - Future obligations from realised policies & None \\
\hline & - Public net assets and their changes & Poor and unreliable \\
\hline & - Tax collection & Yes \\
\hline & - Public expenditure & Yes \\
\hline & - Compliance with spending permissions & Yes \\
\hline & - Cash flows & Yes \\
\hline
\end{tabular}

The Italian case gives evidence that a strong devolution process does not necessarily match with advanced accounting reforms. A relevant issue that arises from the present work questions whether there are significant relationships between the degree of power devolution and the accounting and budgeting systems reforms. Further researches will be able to investigate these kind of relationships in countries that are devolving powers - e.g. Spain and France - or that are old federations - e.g. USA and Switzerland.

\section{BIBLIOGRAPHY}

ANSELMI, L. (2003) Percorsi aziendali per le pubbliche amministrazioni. Torino: Giappichelli.

Borgonovi, E. (1996) Principi e sistemi aziendali per le amministrazioni pubbliche. Milano: Egea.

BRUSCA, I. and V. CONDOR (2002) "Towards the harmonisation of local accounting systems in the international context", Financial Accountability \& Management, 18(2), pp. 129-162.

CAPERCHIONE, E. and R. MUSSARI (2002) "Government budgeting and accounting reform in Italy", J. Chan and C. Xiaoyue (Eds.), Models of Public Budgeting and Accounting, pp. 305-331. OECD Journal on Budgeting, vol. 2, Supp. 1 (Paris: OECD).

CHAN, J. and C. XIAOYUE (Eds.) Models of Public Budgeting and Accounting. OECD J ournal on Budgeting, vol. 2, Supp. 1 (Paris: OECD). 
CHRISTIAENS, J . (2004) "Capital assets in governmental accounting reforms: comparing Flemish technical issues with international standards", European Accounting Review, 13(4), pp. 743-770.

CONTE, C. (1999) "La contabilità analitica per centri di costo nelle amministrazioni dello Stato, in Banca d'Italia", I Controlli delle Gestioni Pubbliche, pp. 45-62, (Perugia).

DAHRENDHORF, R. (2001) Dopo la democrazia. Roma-Bari: Laterza.

Della Cananea, G. (2002) "Il federalismo fiscale italiano è compatibile con I'Unione economica e monetaria?", paper presented at the Cogest Conferences about Conti Pubblici e Controlli: Prospettive e Problemi, Roma, October $24^{\text {th }}$.

DELLA PORTA, D. and A. VAnNucCl (1999) Corrupt Exchanges; Actors, Resources and Mechanisms of Political Corruption. New York: De Gruyter.

DreBin, A.R.; Chan, J.L. and L.C. Ferguson (1981) Objectives of Accounting and Financial Reporting for Governmental Units: a Research Study, vol. I and II. Chicago: National Council on Governmental Accounting.

ELAZAR, D.J . (1987) Exploring Federalism. The University of Alabama Press.

GASB - Governmental Accounting Standards Board (1987) Concept Statement $n^{\circ} 1$, Objectives of Financial Reporting (Norwalk).

- (1994) Concept Statement $n^{\circ} 2$, Service Efforts and Accomplishment Reporting (Norwalk).

- (1999) Statement $n^{\circ}$ 34, Basic Financial Statements - and Management's Discussion and Analysis - for State and Local Governments (Norwalk).

GRAY, A. and B. J ENKINS (1993) "Codes of accountability in the new public sector", Accounting, Auditing \& Accountability J ournal, 6(3), pp. 52-67.

HooD, C. (1991) "A public management for all seasons", Public Administration, 69(1), pp. 3-19.

- (1995) "The New Public Management in the 1980s: Variations on the theme", Accounting, Organisations and Society, 20(2/3), pp. 93-110.

- (1998) The Art of the State: Culture, Rhetoric, and Public Management. Oxford: Clarendon.

IFAC (1994) Occasional Paper 1 Implementing Accrual Accounting in Government: The New Zealand Experience. New York: International Federation of Accountants.

- (1997) Occasional Paper 3 Perspectives on Accrual Accounting. New York: International Federation of Accountants. 
IFAC PSC - The International Federation of Accountants Public Sector Committee (1995) Study 5, Definition and Recognition of Assets. New York: International Federation of Accountants.

- (1995) Study 6, Accounting for and Reporting Liabilities. New York: International Federation of Accountants.

- (1996) Study 8, The Government Financial Reporting Entity. New York: International Federation of Accountants.

- (1996) Study 9, Definition and Recognition of Revenues. New York: International Federation of Accountants.

- (2000) Study 11 - Government Financial Reporting, Accounting Issues and Practices. New York: International Federation of Accountants.

- (2003) Study 14 - Transition to the Accrual Basis of accounting: Guidance for Governments and Government Entities (Second Edition). New York: International Federation of Accountants.

IMF - International Monetary Fund (2001) Manual on Fiscal Transparency. Washington D. C. : International Monetary Fund, Fiscal Affairs Dept.

J ONES, R. and M. Pendlebury (2000) Public Sector Accounting. Harlow: Pearson Education Limited.

LADU, G. (2001) "Federalismo fiscale, autonomia finanziaria, gestione finanziaria e controlli nel quadro delle riforme in corso in Italia", Studi Parlamentari e di Politica Costituzionale, $n^{\circ} 131,1^{\circ}$ trimestre 2001, pp. 49-63.

LAPSLEY, I. and J. PALLOT (2000) "Accounting, management and organizational change: A comparative study of local government", Management Accounting Research, 11, pp. 213-229.

LÜDER, K. and R. J ONES (Eds.) (2003) Reforming Governmental Accounting and Budgeting in Europe. Frankfurt am Main: PricewaterhouseCoopers, Fachverlag Moderne Wirtschaft.

MEAD, D. M. (2001) An Analyst's Guide to Government Financial Statements. Governmental Accounting Standards Board.

Mele, R. (2003) Economia e Gestione delle Imprese di Pubblici Servizi tra Regolamentazione e Mercato. Padova: Cedam.

MONTESINOS, V. and J.M. VeLA (Eds.) (2002) Innovations in Governmental Accounting. Boston: Kluwer.

Mueller, D. C. (1979) Public Choice. Cambridge University Press.

MuLgan, R. (2000) "Accountability: an ever-expanding concept?", Public Administration, 78(3), pp. 555-573. 
MussarI, R.; GRossI, G. and A. CAStelnuovo (2003) "Italy", K. Lüder and R. Jones (Eds.) Reforming Governmental Accounting and Budgeting in Europe. Frankfurt am Main: PricewaterhouseCoopers, Fachverlag Moderne Wirtschaft.

OATES, W. (1999) "An Essay on Fiscal Federalism", J ournal of Economic Literature, 37, September.

OECD - Organisation for Economic Co-operation and development/World Bank (2003) Survey on Budget Practices and Procedures, http:/ / ocde. dyndns. org.

ONGARO, E. (2003) "Problematiche emergenti di accountability nel contesto del decentramento e delle riforme del management pubblico", F. PeZZANI (Eds.) L'accountability delle amministrazioni pubbliche. Milano: Egea, pp. 33-51.

PACIFICO, L. (1999) "Il budget dello Stato, in Banca d'Italia", I Controlli delle Gestioni Pubbliche, pp. 649-654 (Perugia).

PAVAn, A. (2003) "La contabilità di stato tra necessità di governo e informazione agli elettori", Azienda Pubblica, n 1-2, pp. 13-27.

- and Reginato, E. (2004) Programmazione e controllo nello stato e nelle altre amministrazioni pubbliche. Gestione per obiettivi e contabilità economica. Milano: Giuffrè.

PeZzANI, F. (Eds.) (2003) L'accountability delle amministrazioni pubbliche. Milano: Egea.

Pratt, J.W. and R.J. Zeckhauser (1984) Principal and Agent: the Structure of Business. Boston: Harvard Business School Press.

Ross, S.A. (1973) "The economic theory of agency: the principal's problem", American Economic Review, 63(2), pp. 135-162.

Rowley, C.K. (Eds.) (1987) Democracy and Public Choice. Oxford: Basil Blackwell.

SINCLAIR, A. (1995) "The chameleon of accountability: forms and discourses", Accounting, Organizations and Society, 20(2/3), pp. 219-237.

STECCOLINI, I. (2004) "Is the annual report an accountability medium? An empirical investigation into Italian local governments", Financial Accountability and Management, 20(3), pp. 327-350.

TANZI, V. (2000) The role of the State and the Quality of the Public Sector, IMF Working Paper, n. 36, March.

TREMONTI, G. and G. VitALETTI (1994) II federalismo fiscale. Bari: Laterza. 